\title{
PROPOLIS GATHERING ACTIVITY ACCORDING TO DIFFERENT LOCATIONS IN KAFR EL-SHEIKH GOVERNORATE, EGYPT.
}

Fathy, H. M.*; S. S. awadalla* ; H. M. Mansour** and Zienab A. Hassanin ${ }^{\star *}$

* Econ. Entomol. Dept., Fac. of Agric., Mansoura Univ.

${ }^{* *}$ Apiculture Dept., Plant Protection Res. Inst., Agric. Res. Center, Egypt.

\begin{abstract}
This study was carried out in three districts of Kafr El-Sheikh governorate; Sidi Salem, Kafr El-Sheikh and Qualien. At each lactation 4 honeybee colonies of first hybrid carniolan honeybee were assigned for the study. The propolis was manually collected. Averages of each month were recorded from June 2011 up to May 2012. The obtained results revealed that colonies at Qualien district produced the largest annual average of propolis ( $8.3 \mathrm{~g} /$ colony) followed by that of Sidi Salem $(7.2 \mathrm{~g} /$ colony) and Kafr El-Sheikh which produced the least average $(7.1 \mathrm{~g} /$ colony). In addition, Qualien district, which was the highest in collecting propolis was characterized by high number of camphor (Eucalyptus spp.) tree which is good source for propolis.
\end{abstract}

\section{INTRODUCTION}

Propolis is a resinous substance which is gathered by honeybee from deciduous tree bark and leaves. It is sticky material that bees very efficiently use to seal hive holes or cracks. This natural "glue" is clearly utilized by the industrious honeybee to provide exterior protection to the hive against invasion of any outside contaminants. Bees purposefully place this tacky substance in the area which leads into the bee hive, not only to prevent the entrance of intruders, but to sterilize bees brushing up against it from infection.

Before it is used in the hive, honeybee take this sap, combine it with nectar found in their own secretions and eventually end up with a mixture consisting of wax, pollen and bee bread. For this reason, just chewing on a wad of tree resin won't produce the same therapeutic results as propolis. Bees must transform the resin into propolis (Rita Elkins, 1996).

Propolis (bee glue) is complex mixture, formed from resinous and balmy material, collected by bees from parts of plants (branch, flowers, pollen and buds) and modified in the bee hive by addition of salivate secretions and wax (Ghisalberti, 1979; Pereira et al., 1998 and Povova et al., 2005). Bee use it as a sealer for their hives and more importantly, to prevent the decomposed of creatures which have been killed by bees after an invasion of the hive (Marcucci, 1995 and Jackson, 2001).

Bees apply propolis in a thin layer on internal walls of their hive or other cavities they inhabit. It is used to block holes and crackes, repair combs string the hive borders of the comb and make the entrance easier to defend. Cells of the comb are also polished by propolis (Hegazi, 2000; Abd El-Hady and Hegazi, 2002). 
Fathy, H. M. et al.

Also, propolis is used an "embalming" substance to cover hive invaders which bees have killed but cannot transport out of the hive (Bankova et al., 2000; Hegazi, 2000 and Jackson, 2001).

Propolis is collected in different ways such as the traditional way of scraping frames and boxes that is labor intensive and does not provide pure and large quantities of propolis (Clay, 2002 and Anonymous, 2004).

The average production of propolis per colony per year has been recorded as 10 to $300 \mathrm{~g}$ propolis production depends on the bee strain, the climate, the locations resources (Krell, 1996).

\section{MATERIALS AND METHODS}

The study was carried out in apiary at Sidy Salem, Kafrelsheikh and Qualein districts, Kafr El-Sheikh Governorate from the beginning of June, 2011 to the end of May 2011. Four colonies of first hybrid corniolan honeybee were assigned for the study of each district. All colonies were approximately equal in strength and in number of combs covered with bees and had sufficient food. Colonies were headed with newly and naturally mated queens.

The following investigations were conducted:

\section{Propolis gathering activity:}

Propolis was gathered at 12 day intervals. The propolis was scrapped from the top of combs, inner sides of hive boxes, bottom and entrance of the hives. Also, the propolis was collected from jute located on tops of combs inside the brood chamber. The propolis was scrapped by hand from the top of sacking cloth covered the combs. The collected propolis was weighed in grams. The collected propolis was mixed by a little ratio of wax.

The methods collected propolis similar by (El-Shaarawi and Serag ElDein, 2005 and Mostafa, 2009). The collected propolis samples from every tested colony were weighed and stored in deep freezing until using the other tests and evaluation.

\section{RESULTS AND DISCUSSION}

\section{Propolis gathering activity:}

Data in Table (1) and Fig.(1) show that the amount of proplis gathered in Sidi Salm district. The total of propolis amount during one year were $(86.3 \mathrm{~g} / \mathrm{colony})$ and average amount were $(7.2 \mathrm{~g} / \mathrm{colony})$. The least amounts of proplis at Sidi Salem district recorded during December 2011 and January 2012 were $(2.1 \mathrm{~g} /$ colony and $2.2 \mathrm{~g} /$ colony $)$, respectively. The highest amounts were recorded during July and August were $(16.6 \mathrm{~g} /$ colony and 16.2 g/colony), respectively. Monthly collected of propolis recorded highly percentage during July, August and September, 2011 were (19.2, 18.8 and 9.4 g/colony), respectively and during 2012 April, May and June 2011 recorded $7.3,9.6$ and $11.1 \mathrm{~g} /$ colony, respectively. While the smallest percentage recorded during months, October, November 2011, January, 
February and March 2012, were 5.3, 3.9, 2.9, 2.5, 4.9 and $6.1 \mathrm{~g} /$ colony, respectively. Also, data in Table (1) observed that the amount of propolis was influenced by the relative humidity and temperature the activity of propolis gathering was $\left(33-33.5^{\circ} \mathrm{C}\right)$ and $(51.0-53.5 \mathrm{RH})$, respectively.

Table (1): Monthly average amounts of propolis (in gm) collected by honeybee colonies during the season of 2011/2012 in ratio Sidy Salem district, Kafrelsheikh governorate.

\begin{tabular}{|c|c|c|c|c|c|c|}
\hline \multirow{2}{*}{ Months } & \multirow{2}{*}{$\begin{array}{c}\text { Average per } \\
\text { colony }\end{array}$} & \multirow{2}{*}{$\%$} & \multicolumn{2}{c|}{ Temperature } & \multicolumn{2}{c|}{ Humidity } \\
\cline { 4 - 7 } & & Exo & Endo & Exo & Endo \\
\hline June & 9.6 & 11.1 & 31.3 & 33.0 & 47.0 & 54.5 \\
\hline July & 16.6 & 19.2 & 33.5 & 32.5 & 51.3 & 54.0 \\
\hline August & 16.2 & 18.8 & 33.0 & 33.0 & 53.5 & 58.0 \\
\hline September & 8.1 & 9.4 & 31.3 & 32.5 & 52.0 & 56.0 \\
\hline October & 4.6 & 5.3 & 25.8 & 32.0 & 52.5 & 56.0 \\
\hline November & 3.4 & 3.9 & 20.4 & 32.0 & 61.5 & 58.0 \\
\hline December & 2.1 & 2.4 & 17.0 & 32.0 & 62.5 & 55.0 \\
\hline January & 2.2 & 2.5 & 18.2 & 31.8 & 62.0 & 55.0 \\
\hline February & 3.8 & 4.4 & 17.4 & 32.5 & 63.0 & 53.0 \\
\hline March & 5.2 & 6.1 & 20.9 & 33.0 & 62.0 & 52.0 \\
\hline April & 6.3 & 7.3 & 26.4 & 32.5 & 48.5 & 50.0 \\
\hline May & 8.2 & 9.6 & 30.5 & 33.0 & 53.0 & 51.0 \\
\hline Total & 86.3 & 100 & 305.7 & 389.8 & 668.8 & 652.5 \\
\hline Average & 7.2 & 8.3 & 25.5 & 32.5 & 55.7 & 54.4 \\
\hline
\end{tabular}

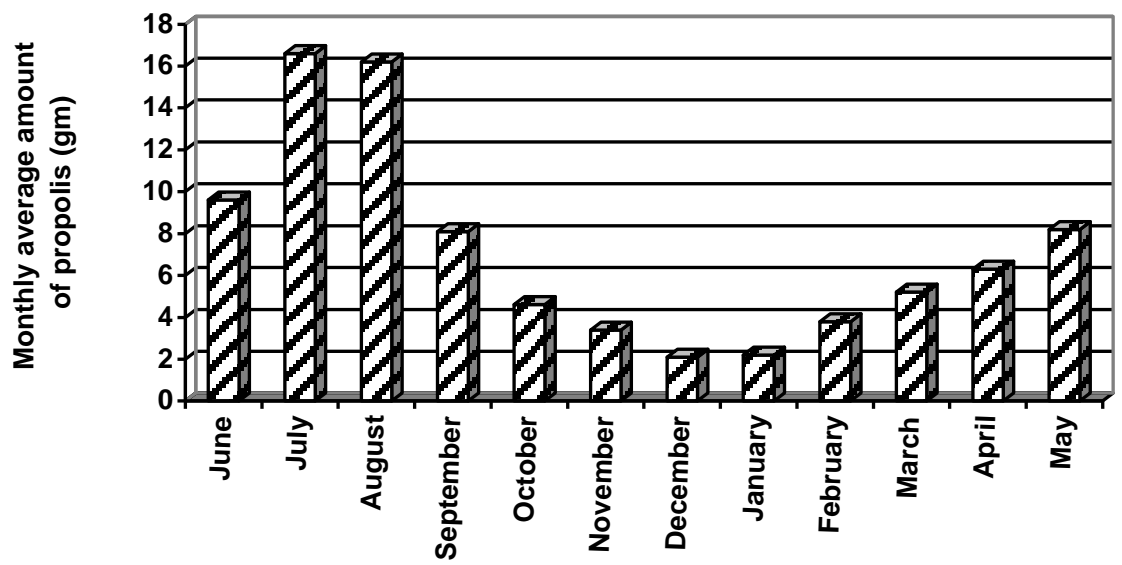

Fig. (1): Monthly average amounts of propolis (in gm) collected by honeybee colonies during the season of 2011/2012 in ratio Sidy Salem district, Kafrelsheikh governorate.

Data in Table (3) and Figure (2) showed that the total amount of propolis gathering during one year at Kafr El-Sheikh district was (86.5 $\mathrm{g} /$ colony) with average ( $7.2 \mathrm{~g} /$ colony). 
Table (2): Correlation coefficient between temperature, relative humidity and propolis in Sidi Salem location

\begin{tabular}{|c|c|c|c|c|c|}
\hline & Propolis & Temp. exo & Temp endo & Humid. exo. & Humid. endo \\
\hline Propolis & 1.00 & - & - & - & - \\
\hline Temp. exo. & $0.870^{\star *}$ & 1.00 & - & - & - \\
\hline Temp. endo & $0.593^{*}$ & $0.585^{\star}$ & 1.00 & - & - \\
\hline Humid. exo & -0.614 & $0.866^{* *}$ & -0.429 & 1.00 & - \\
\hline Humid. endo & 0.121 & 0.043 & -0.348 & 0.157 & 1.00 \\
\hline
\end{tabular}

${ }^{\star *}$ correlations significant at the 0.01 level (2-talled)

- correlation is significant at the 0.05 level (2-talled)

Table (3): Monthly average amounts of propolis (in gm) collected by honeybee colonies during the season of 2011/2012 in ratio Kafrelsheikh district, Kafrelsheikh governorate.

\begin{tabular}{|c|c|c|c|c|c|c|}
\hline \multirow{2}{*}{ Months } & \multirow{2}{*}{$\begin{array}{c}\text { Average per } \\
\text { colony }\end{array}$} & \multirow{2}{*}{$\%$} & \multicolumn{2}{c|}{ Temperature } & \multicolumn{2}{c|}{ Humidity } \\
\cline { 4 - 7 } & & Exo & Endo & Exo & Endo \\
\hline June & 10.3 & 12.1 & 32.3 & 33.0 & 46.5 & 55.0 \\
\hline July & 15.9 & 18.7 & 34.5 & 32.4 & 51.2 & 56.0 \\
\hline August & 15.2 & 17.9 & 34.0 & 33.0 & 52.0 & 58.0 \\
\hline September & 6.5 & 7.6 & 32.3 & 32.2 & 51.0 & 56.0 \\
\hline October & 3.8 & 4.5 & 26.8 & 32.0 & 52.2 & 55.0 \\
\hline November & 3.5 & 4.1 & 21.4 & 32.0 & 61.5 & 59.0 \\
\hline December & 1.9 & 2.2 & 17.2 & 32.5 & 61.9 & 55.0 \\
\hline January & 2.3 & 2.7 & 19.2 & 32.5 & 61.5 & 54.5 \\
\hline February & 4.5 & 5.3 & 18.4 & 33.0 & 62.3 & 56.0 \\
\hline March & 6.2 & 7.3 & 21.9 & 33.0 & 61.0 & 52.0 \\
\hline April & 7.1 & 8.4 & 27.9 & 32.5 & 49.5 & 50.0 \\
\hline May & 7.8 & 9.2 & 31.5 & 33.0 & 52.5 & 51.0 \\
\hline Total & 85 & 100 & 317.4 & 391.1 & 663.1 & 657.5 \\
\hline Average & 7.1 & 8.3 & 26.5 & 32.6 & 55.3 & 54.8 \\
\hline
\end{tabular}

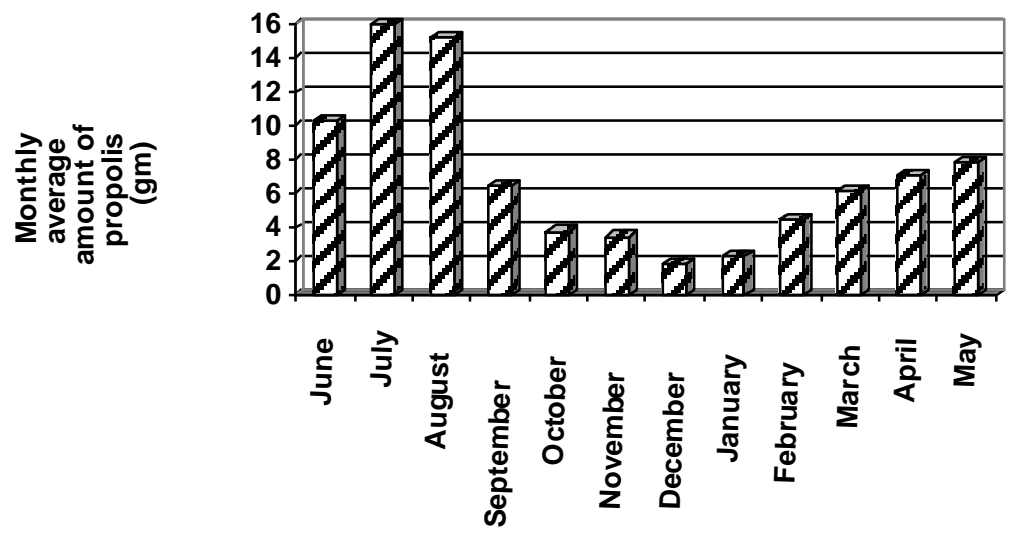

Fig. (2): Monthly average amounts of propolis (in gm) collected by honeybee colonies during the season of 2011/2012 in ratio Kafrelsheikh district, Kafrelsheikh governorate 
Monthly collected of propolis recorded highly percentage during July, August and September were 18.7, 17.9 and $7.6 \mathrm{~g} /$ colony, respectively and during 2012 recorded medium percentage in months April, May and June were $7.3,9.6$ and $11.1 \mathrm{~g} /$ colony, respectively. The highest amounts of propolis at Kafr El-Sheikh district recorded during July and August 15.9 and $15.2 \mathrm{~g} /$ colony, respectively. While the months April, May and June 2012 recorded 7.1, 7.8 and $10.3 \mathrm{~g} /$ colony, respectively. The least amounts of propolis at same district were 3.5, 1.9 and $3.2 \mathrm{~g} /$ colony in November, December and January 2012, respectively. The amount of propolis was influenced by the temperature and humidity percentage when recorded (15.9 and $15.2 \mathrm{~g} /$ colony) at temperature $\left(34.5\right.$ and $\left.34.0^{\circ} \mathrm{C}\right)$ and humidity $(51.2$ and $52.0 \%$ R.H) during months July and August.

The amounts of propolis gathered at Qualien district in Table (5) and Figure (3) recorded (98.8 g/colony) and average ( $8.2 \mathrm{~g} /$ colony) during one year. The least amount was recorded during December $(2.2 \mathrm{~g} /$ colony) and January ( $2.9 \mathrm{~g} /$ colony). The highest amount was recorded during July (17.9 $\mathrm{g} /$ colony) and August (17.2 g/colony). The smallest percentage recorded during months November, December and January (4.1, 2.2 and $2.9 \mathrm{~g} /$ colony), respectively.

The amount of propolis collected per colony depends on many factors such as strength of colony, plant sources, weather conditions and needs of hive. These results are in harmony with the results of (Marleto and Olivera 1981; Kassem, 2000; Serag El-Dien, 2004; Mostafa, 2009 and Zedan, 2011).

Table (4): Correlation coefficient between temperature, relative humidity and propolis in Kafr El-Sheikh location

\begin{tabular}{|c|c|c|c|c|c|}
\hline & Propolis & Temp. exo & Temp endo & Humid. exo. & Humid. endo \\
\hline Propolis & 1.00 & - & - & - & - \\
\hline Temp. exo. & $0.831^{\star *}$ & 1.00 & - & - & - \\
\hline Temp. endo & 0.346 & 0.095 & 1.00 & - & - \\
\hline Humid. exo & $-0.637^{\star}$ & $-0.901^{\star *}$ & 0.035 & 1.00 & - \\
\hline Humid. endo & 0.131 & -0.010 & -0.315 & 0.195 & 1.00 \\
\hline
\end{tabular}

** correlations significant at the 0.01 level (2-talled)

* correlation is significant at the 0.05 level (2-talled)

Table (5): Monthly average amounts of propolis (in gm) collected by honeybee colonies during the season of 2011/2012 in ratio Qualien district, Kafrelsheikh governorate.

\begin{tabular}{|c|c|c|c|c|c|c|}
\hline \multirow{2}{*}{ Months } & \multirow{2}{*}{$\begin{array}{c}\text { Average per } \\
\text { colony }\end{array}$} & \multirow{2}{*}{$\%$} & \multicolumn{2}{|c|}{ Temperature } & \multicolumn{2}{c|}{ Humidity } \\
\cline { 4 - 6 } & & Exo & Endo & Exo & Endo \\
\hline June & 12.5 & 12.7 & 32.3 & 32.0 & 48.1 & 55.0 \\
\hline July & 17.8 & 18.0 & 34.5 & 33.0 & 54.3 & 56.0 \\
\hline August & 17.2 & 17.4 & 34.0 & 33.0 & 52.7 & 57.0 \\
\hline September & 8.2 & 8.3 & 32.3 & 32.5 & 54.8 & 56.0 \\
\hline October & 4.1 & 4.2 & 26.8 & 32.3 & 55.0 & 54.5 \\
\hline November & 4 & 4.1 & 21.4 & 32.3 & 59.5 & 59.0 \\
\hline December & 2.2 & 2.2 & 17.2 & 32.0 & 62.0 & 54.5 \\
\hline January & 2.9 & 2.9 & 19.2 & 32.0 & 61.5 & 54.0 \\
\hline February & 5.5 & 5.6 & 18.4 & 33.0 & 62.3 & 54.0 \\
\hline March & 7.2 & 7.3 & 21.9 & 33.2 & 61.6 & 54.0 \\
\hline April & 8.2 & 8.3 & 27.9 & 32.5 & 50.2 & 50.0 \\
\hline May & 8.9 & 9.0 & 31.5 & 33.0 & 52.7 & 52.0 \\
\hline Total & 98.7 & 100 & 317.4 & 390.8 & 674.7 & 656 \\
\hline Average & 8.2 & 8.3 & 26.5 & 32.6 & 56.2 & 54.7 \\
\hline
\end{tabular}




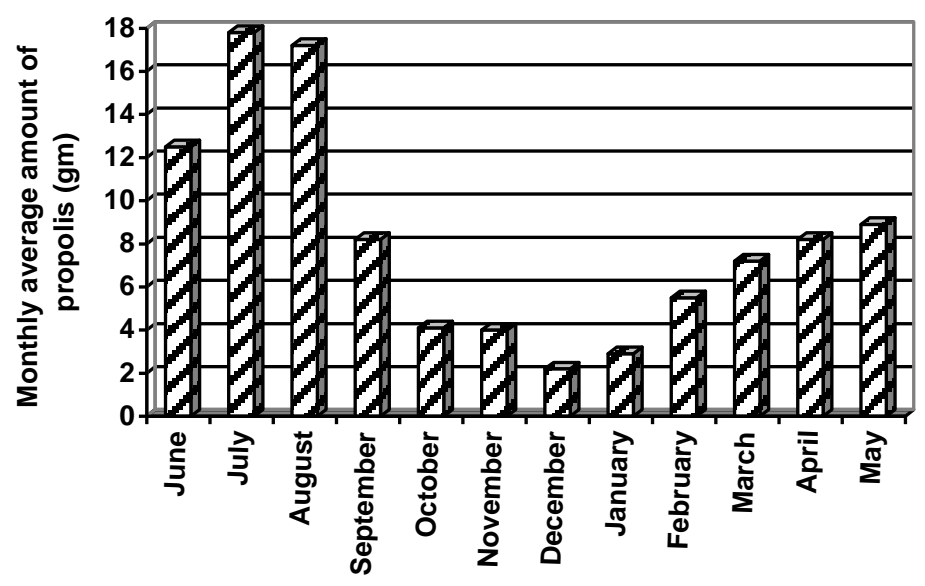

Fig. (3): Monthly average amounts of propolis (in gm) collected by honeybee colonies during the season of 2011/2012 in ratio Qualien district, Kafrelsheikh governorate.

Table (6): Correlation coefficient between temperature, relative humidity and propolis in Qualin location

\begin{tabular}{|c|c|c|c|c|c|}
\hline & Propolis & Temp. exo & Temp endo & Humid. exo. Humid. endo \\
\hline Propolis & 1.00 & - & - & - & - \\
\hline Temp. exo. & $0.840^{\star *}$ & 1.00 & - & - & - \\
\hline Temp. endo & 0.489 & 0.288 & 1.00 & - & - \\
\hline Humid. exo & $-0.634^{\star}$ & $-0.860^{\star *}$ & 0.018 & 1.00 & - \\
\hline Humid. endo & 0.173 & 0.065 & 0.077 & 0.194 & 1.00 \\
\hline
\end{tabular}

${ }^{\star \star}$ correlations significant at the 0.01 level (2-talled)

* correlation is significant at the 0.05 level (2-talled)

Also, the above results obtained are higher than that obtained by Ayoub (1987) who cleared that the amounts of propolis collected were 14.62, $10.40,6.30$ and $8.50 \mathrm{~g} /$ colony in summer, spring, winter and autumn, respectively. The results obtained are higher than that obtained by Ghazala (1998) who found that the carniolan hybrid colonies (F1) collected monthly amounts of propolis more than each of carniolan honebee and carniolan hybrid (F2) colonies, the amounts of propolis were: 9.41, 6.29and 5.36 $\mathrm{g} /$ colony for the three strains, respectively. Also, El-Shaarawi and Serag ElDien (2005) found that the propolis was manually collected. Averages of each month were recorded from November 2003 up to October 2004. The obtained results revealed that colonies at Qualien district produced the largest annual average of propolis ( $8.88 \mathrm{~g} /$ colony) followed by that of Sidi Salem (6.16 g/colony). 


\section{REFERENCES}

Abd El-Hady, F.K. and A.G. Hegazi (2002). Egyptian propolis; chemical composition, antiviral and antimicrobial activities for east Nile Delta Propolis. Zeit Schrift.fur.Naturfor Schung, 57: 386-394.

Anonymous (2004). Proplis what is it? www.use survey. Retrieved from: http:// propolis.virtualave.net/anglies/Uk proplis.htm

Ayoub, A.A. (1987). Studies on propolis gathering by honey bees, Apis mellifera. M.Sc. Thesis, Alex. Univ.

Bankova, V.; S. Castro and M.C. Marcucci (2000). Propolis: recent advances in chemistry and plant origin. Apidologie, 31(1):3-15.

Clay, H. (2002). Propolis collection: a value added potential. Printed in Hive Lights Vol. 14, Retrieved from www.honeycouncil.ca/proplis/html.

El-Shaarawi, M.O. and F.S. Serag El-Dien (2005). Propolis and pollen grains gathering activity of the worker honeybees in some districts, Kafr ElSheikh governorate. Egypt. J. Agric. Res., 83(3): 1051-1059.

Ghazala, N.A. (1998). Studies on propolis production. M.Sc. Thesis, Fac. of Agric., Moshtohor, Zagazig Univ., 132 pp.

Ghisalberti, E.L. (1979). Propolis: A Review. Bee World, 60: 59-84.

Hegazi, A.G. (2000). Propolis an overiew. Retrieved from: http://www.apinetla.co.ar/congreso/c5.pdf.

Jackson, D. (2001). Don Fielder, propolis and beehive botanicals. American Bee Journal, 141: 119-122.

Kassem, S.I. (2000). Ecological and physiological studies on queen rearing of some honeybee races (Apis mellifera L.). Ph.D. Thesis, Fac. Agric., Moshtohor, Zagazig Univ. 139

Krell, R. (1996). Value-added products from bee keeping FAO Agricultural Services Bulletin. No. 124, Food and Agriculture Organization of the United Nations, Rome, Italy.

Marcucci, M.C. (1995). Propolis: chemical composition , biological properties and therapeutical activity. Apidologie, 26: 83-99.

Marletto, F. and G. Olivero (1981). Collection and uses of propolis by honeybee in Italian Apicoltore Moderno, 72(4): 131-140.

Mostafa, Sh.N. (2009). Studies on propolis: gathering, quality and antibacterial activity. M.Sc. Thesis, Fac. Agric.Cairo Univ., 196 pp.

Pereira, A.S.; A.C. Pinto; J.N. Cardoso and F.R. Aquino Neto (1998). Application of high temperature, high resolution gas chromatography to crude extracts of propolis. J. High Resol. Chromatogr., 21(7): 396400.

Popova, M.; S. Silici; O. Kaftanoglu and V. Bankova (2005). Antibacterial activity of Turkish propolis and its qualitative and quantitative chemical composition. Phytomedicine, 12: 221-228.

Rita Elkings, M.A. (1996). Bee pollen, Royal Jelly, propolis and honey on extraordinary energy and health promoting ensemble. Canada, Woodland Publishing, 32. 
Fathy, H. M. et al.

Serag El-Dien, F.Sh. (2004). Comparative study of some products of Italian and carniolan honeybee hybrids at Kafr El-Sheikh governorate. J. Agric. Sci. Mansoura Univ., 29(1): 409-416.

Zedan, O.A.A. (2011). Studies on some honeybee hybrids activity. Ph.D. Thesis, Fac. Agric., Tanta Univ., 147 pp.

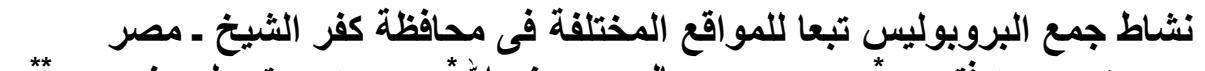

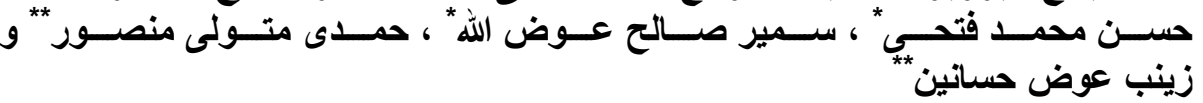

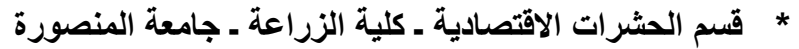

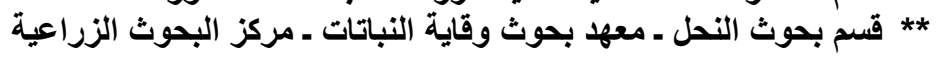

$$
\begin{aligned}
& \text { أجريت هذه الدراسة فى ثلاثة مر اكز بمحافظة كفر الثيخ وهى سيدى سـالم ، كفر الثيخ } \\
& \text { وقلين. } \\
& \text { تم تخصيص اربعة طو ائف بكل موقع للار اسة. وتم جمع البروبوليس يدويا خـلال } \\
& \text { عام كامل فى الفترة من يونيو } 2011 \text { حتى مايو } 2012 .
\end{aligned}
$$

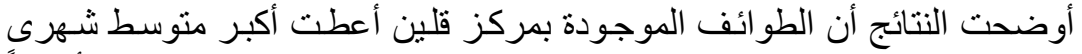

$$
\begin{aligned}
& \text { من البروبوليس (8.3 جم/طائفة) ثم طو ائف مركز سيدى سـالم (7.2 (7.2 جم/طائفة) و أخير اً }
\end{aligned}
$$

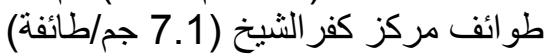

$$
\begin{aligned}
& \text { و على ذلك وجد أن أفضل إنتاج للبروبوليس كان بمركز قلين ـ محافظة كفر الثيخ وذلك }
\end{aligned}
$$

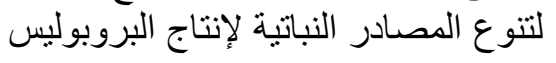

$$
\begin{aligned}
& \text { كلية الزراعة - جامعة المنصورة } \\
& \text { مركز البحوث الزراعيه } \\
& \text { قأم بتحكيم البحث ألد / لئل عبد الستار }
\end{aligned}
$$

